Available online at:
Thttp:llejournal.amikompurwokerto.ac.id/index.php/telematikal
Telematika
Accreditated SINTA “2” Kemenristek/BRIN, No. 85/M/KPT/2020

\title{
Prediction Model Grade Point Average using Backpropagation Neural Network and Multiple Linear Regression
}

\author{
Lusiana Efrizoni ${ }^{1}$, Sarjon Defit ${ }^{2}$ \\ ${ }^{1}$ Teknik Informatika, STMIK Amik Riau \\ ${ }^{2}$ Teknik Informatika, Universitas Putra Indonesia YPTK Padang \\ E-mail: 1lusiana@sar.ac.id, 2sarjond@yahoo.co.uk
}

\section{A R T I CL E I N F O}

History of the article:

Received September 9, 2020

Revised December 10, 2020

Accepted February 20, 2021

\section{Keywords:}

Neural Network,

Backpropagation,

Multiple Linier Regression,

Prediction,

Grade Point Average

\section{Correspondece:}

Telepon: +62 85767434270

E-mail: lusiana@sar.ac.id

\begin{abstract}
ABSTRAK
Education in the 21st century equips students with knowledge and information and the success of achieving academic achievements during the learning process. Students' academic achievement can be seen from various aspects: the Grade Point Average. So far, efforts to predict GPA have not been made. In fact, if the student's Grade Point Average can be predicted from an early age, the study program can implement a policy to improve graduates' quality and make planning, study escort, and guidance more intensive. Based on this urgency, this study aims to produce a predictive model for the GPA of STMIK Amik Riau students in the odd semester of 2019, using the Backpropagation Neural Network algorithm and Multiple Linear Regression. Backpropagation's architectural model is 8 architectures, and 4-5-1 is the best architectural model with MSE at the time of training = 0.00099965532 and MSE during network validation $=0.0038793$ with an epoch of 102 iterations and the resulting accuracy value of $95.24 \%$. Meanwhile, the GPA prediction results, after testing using the Multiple Linear Regression algorithm, obtained an MSE value of $0.0 .27966667 \%$, with a Multiple Correlation coefficient $(\mathrm{R})$ of $\mathrm{R}=0.9774925$ and a coefficient of determination $(\mathrm{R} 2)=$ 0.95549159 . Thus the prediction of student GPA using MLR is accurate because the value of the coefficient of determination (R2) is close to 1 .
\end{abstract}

\section{INTRODUCTION}

The development of science encourages Higher Education to improve the quality of education (Darling-Hammond et al., 2019). The transition of the education paradigm from Teacher Center Learning (TCL) to Student Center Learning (SCL) is one of the efforts made to improve the quality of education (Kasim and Aini, 2012). The purpose of education is not only to equip students with knowledge and information, but also to succeed in achieving academic achievements during the learning process. One aspect that is used as a reference for assessing student academic achievement is the Grade Point Average (GPA). The Grade Point Average (GPA) is a number that shows a student's cumulative learning achievement or progress from the first semester to the last semester that has been taken. If a student's Grade Point Average (GPA) can be predicted from an early age, the study program can implement a policy to improve the quality of student graduates in planning, study escort, and intensive guidance to students, which is indicated by the GPA below the quality standards set by the educational institution. According to Herdianto (2013), prediction is a process of systematically estimating something that is most likely to happen in the future based on past and present information that is owned. 
Based on this urgency, this research was conducted to create a model that could predict GPA using data from the 2016 Amik Riau STMIK students, which were obtained from the Higher Education Database (PDPT), and the Sisfo STMIK Amik Riau Team. The algorithms used to make prediction models for the GPA are Backpropagation Neural Network (BNN) and Multiple Linear Regression (MLR). Algorithm performance will be measured, after the model is generated by each algorithm. BNN is very useful for deep neural networks working on error-prone projects (Lesnussaa et al., 2018). The BNN algorithm has been widely applied in several domains. Anjar Wanto et al. (2017) predict population density using a combination of binary and linear sigmoid functions with an accuracy rate of $94 \%$. The bipolar sigmoid activation function (tansig) and the linear (purelin) function were used by Najwa, et al. (2017) to predict the rate of return on the rupiah exchange rate to the United States dollar with a MAPE of $153.23 \%$. Furthermore, the prediction of the performance and emission characteristics of the dual fueled $\mathrm{H} 2$ diesel engine, using the trainbfg algorithm with RMSE, MAPE, and KGE parameters, states that the prediction of the Artificial Neural Network (ANN) is in accordance with the experimental results (Javed Syed, et al, 2017). BNN is used to predict the number of newspaper requests (Sakinah et al., 2018), predict students 'abilities (Julpan et al., 2015) and predict students' level of understanding of the material being taught (Sumijan et al., 2016). However, accuracy problems are still a challenge in using the BNN algorithm, in addition to optimization problems and dataset size.

Prediction uses the MLR algorithm, showing a fairly good and precise predictive value (Izzah, Abidatul and Widyastuti, 2017). MLR is used to predict stock value, K-Means and Moving Average (MA) are used to solve the stock's diverging point. Research conducted by Katemba and Djoh (2017) used simple linear regression or simple linear regression to predict coffee demand in Manggarai Regency. Algorithm testing uses MSE and MAPE, with an MSE value of 43.112\% and MAPE 20.001\%. Uayni and Guler (2013) assume the physiology of education, program development, counseling techniques and instructions from a university (PT) uses MLR and its estimation uses the KPSS score, where the dependent variable depends on the ANOVA statistics. Mekparyup et al. (2014) used MLR to predict the average nitrogen oxide per month in Rayong, Thailand. This study builds multiple regression equations with the dependent variable Nitrogen Oxide (NOX), and 4 independent variables, wind speed, wind direction, air temperature and relative humidity. Whereas in this study using MLR to predict the Grade Point Average (GPA) of 2019 Odd Semester students with 1 dependent variable (i.e. Even 18) and 5 independent variables (i.e. Odd16, Even16, Odd17, Even17, and Odd18).

\section{RESEARCH METHODS}

The research framework consists of: data collection, then the data will be trained and tested using the BNN and MLR algorithms, then the performance of each measured algorithm is written in the conclusion. The research framework is presented in Figure 1. 


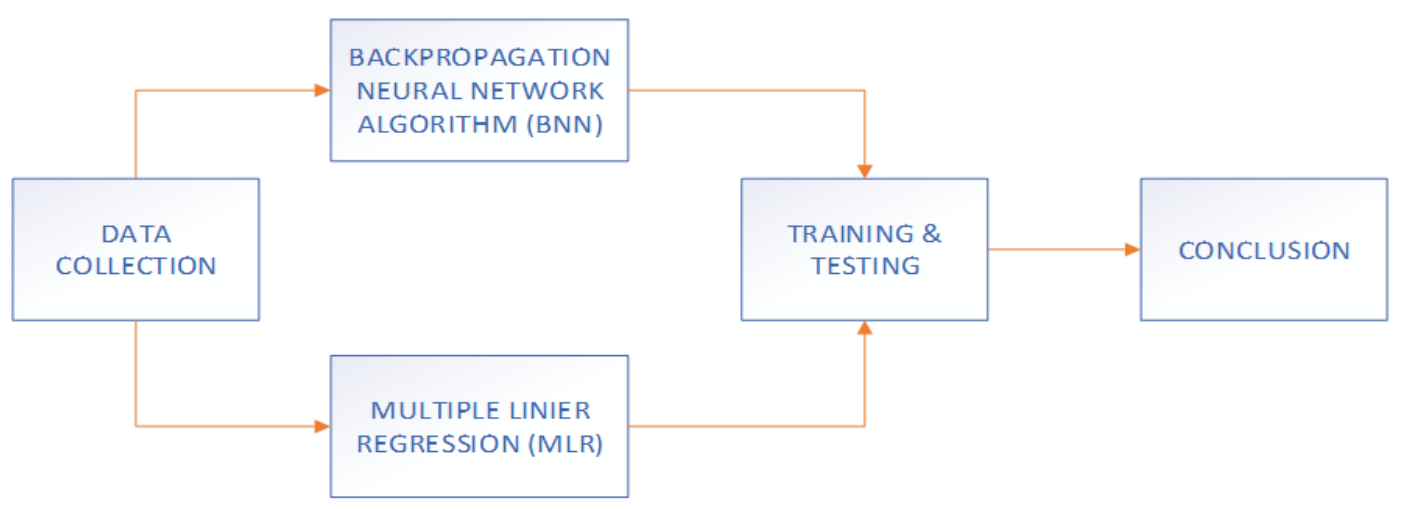

Figure 1. Research framework

\section{Data collection}

The GPA data used is the data of 2016 STMIK Amik Riau students i.e. Odd-2016, Even-2016, Odd2017, Even-2017, Odd-2018, and Even-2018. From existing data, it is cleaned, and incomplete data is discarded/eliminated. After cleaning, the complete data remaining 30 samples, are presented in Table 1.

Table 1. Student Data STMIK Amik Riau 2016

\begin{tabular}{|c|c|c|c|c|c|c|c|c|}
\hline \multirow{2}{*}{ No } & \multirow{2}{*}{ Student_ID } & \multirow{2}{*}{ Student Name } & \multicolumn{2}{|c|}{2016} & \multicolumn{2}{|c|}{2017} & \multicolumn{2}{|c|}{2018} \\
\hline & & & Odd & Even & Odd & Even & Odd & Even \\
\hline 1 & 1610051802001 & Abdul Aziz Al Fadani & 1.99 & 1.76 & 1.95 & 2.54 & 2.49 & 2.64 \\
\hline 2 & 1610051802002 & $\begin{array}{l}\text { Abdurrahman } \\
\text { Agung Akhir }\end{array}$ & 2.86 & 2.80 & 2.86 & 2.90 & 2.92 & 2.96 \\
\hline 3 & 1610051802004 & $\begin{array}{l}\text { Syahputra } \\
\text { Azmi Rahmat }\end{array}$ & 2.88 & 2.78 & 2.97 & 3.07 & 3.12 & 3.20 \\
\hline 4 & 1610051802018 & Endardhi & 2.82 & 2.93 & 3.10 & 3.12 & 3.18 & 3.26 \\
\hline 5 & 1610051802019 & Bambang Permadi & 3.26 & 3.26 & 3.33 & 3.34 & 3.39 & 3.44 \\
\hline 6 & 1610051802021 & Bismi & 3.37 & 3.21 & 3.33 & 3.31 & 3.31 & 3.36 \\
\hline 7 & 1610051802024 & Dedy Alfikri & 2.74 & 2.76 & 2.76 & 2.56 & 2.63 & 2.74 \\
\hline 8 & 1610051802055 & Enjel Setia Syahputra & 3.01 & 3.06 & 3.20 & 3.27 & 3.31 & 3.35 \\
\hline 9 & 1610051802058 & Fika Felanda Ardelia & 3.16 & 3.47 & 3.59 & 3.64 & 3.59 & 3.57 \\
\hline 10 & 1610051802059 & $\begin{array}{l}\text { Four Putra Aulia } \\
\text { Gugus Andri }\end{array}$ & 3.40 & 3.55 & 3.48 & 3.16 & 2.94 & 2.74 \\
\hline 11 & 1610051802040 & Hermawan & 3.33 & 3.04 & 3.09 & 3.14 & 3.15 & 3.24 \\
\hline 12 & 1610051802041 & Hafizh Nirwanda & 2.58 & 2.66 & 2.89 & 2.91 & 2.98 & 3.09 \\
\hline 13 & 1610051802044 & Indri Febrianti & 3.54 & 3.51 & 3.64 & 3.54 & 3.53 & 3.56 \\
\hline 14 & 1610051802045 & Intan Urfa, Ks & 3.54 & 3.51 & 3.63 & 3.70 & 3.70 & 3.72 \\
\hline 15 & 1610051802046 & Irfansyah & 2.70 & 1.66 & 1.45 & 1.59 & 1.58 & 1.45 \\
\hline 16 & 1610051802047 & Ishad Nasoha & 3.14 & 3.20 & 3.25 & 3.27 & 3.23 & 3.26 \\
\hline 17 & 1610051802051 & Juni Kanasti Dewi & 3.13 & 3.25 & 3.34 & 3.47 & 3.43 & 3.45 \\
\hline 18 & 1610051802052 & Kadek Mirnawati & 3.61 & 3.39 & 3.45 & 3.51 & 3.55 & 3.57 \\
\hline 19 & 1610051802062 & M. Quraish Shihab & 3.07 & 3.33 & 3.50 & 3.40 & 3.44 & 3.50 \\
\hline 20 & 1610051802103 & Santia Tanjung & 3.39 & 3.28 & 3.31 & 3.39 & 3.39 & 3.45 \\
\hline 21 & 1610051802104 & Satrio Wijaksono & 2.89 & 2.91 & 3.12 & 3.21 & 3.25 & 3.30 \\
\hline 22 & 1610051802105 & Sulistiono & 3.25 & 3.30 & 3.44 & 3.26 & 3.29 & 3.30 \\
\hline 23 & 1610051802106 & Syukriman Sarza & 3.01 & 2.99 & 3.06 & 3.14 & 3.20 & 3.23 \\
\hline 24 & 1610051802107 & Syawiransyah & 3.16 & 3.03 & 3.24 & 3.31 & 3.36 & 3.43 \\
\hline 25 & 1610051802108 & Taufik Ramadan Putra & 3.74 & 3.73 & 3.78 & 3.63 & 3.50 & 3.56 \\
\hline 26 & 1610051802109 & Teguh Alfalah & 3.12 & 3.24 & 3.31 & 3.38 & 3.42 & 3.42 \\
\hline 27 & 1610051802110 & Tri Agustia Ningsih & 3.18 & 2.95 & 2.98 & 3.12 & 3.18 & 3.24 \\
\hline 28 & 1610051802114 & Wahhadi Anfar & 3.09 & 3.03 & 3.14 & 3.22 & 3.19 & 3.23 \\
\hline 29 & 1610051802115 & Wahyu Fadhillah & 3.54 & 3.61 & 3.63 & 3.66 & 3.65 & 3.68 \\
\hline 30 & 1610051802125 & Zel Afriadi & 3.16 & 3.15 & 3.26 & 3.32 & 3.32 & 3.34 \\
\hline
\end{tabular}

\section{Backpropagation Neural Network (BNN) Algorithm}

\section{Data Normalization (Preprocessing)}

The first step that must be done is to normalize the data, which is one of the activities in preprocessing. In ANN, the data must be normalized first. The function used in data normalization is the sigmoid function. 
Where normalized data will produce a value between 0 and 1 (not 0 and 1). The data transformation is carried out at smaller intervals using equation (1).

$$
X^{\prime}=\frac{0.8(x-a)}{b-a}+0.1
$$

Where: $X^{\prime}=$ Data normalization; $\mathrm{x}=$ Data to be normalized; $\mathrm{a}=$ Lowest data $\mathrm{b}=$ Highest data

The results of normalization in training data of 21 samples are presented in Table 2 . The training data is Odd-2016 to Even-2017 with the target element is Odd-2018. Furthermore, for testing data, the sample used is a sample of 22 to 30 . The results of data normalization in the testing data are presented in Table 3 (i.e. Even-2016 to Odd-2018 with the target element being Even-2018).

Table 2.Normalization of Training Data for Odd-2016 to 2017 Semesters, with Odd-2018 Targets

\begin{tabular}{|c|c|c|c|c|c|c|c|}
\hline \multirow[b]{2}{*}{ No } & \multirow[b]{2}{*}{ Student_ID } & \multirow[b]{2}{*}{ Student Name } & \multicolumn{4}{|c|}{ Input } & \multirow{2}{*}{$\begin{array}{c}\text { Target } \\
\text { Odd- } \\
2018\end{array}$} \\
\hline & & & $\begin{array}{l}\text { Odd- } \\
2016\end{array}$ & $\begin{array}{c}\text { Even- } \\
2016\end{array}$ & $\begin{array}{l}\text { Odd- } \\
2017\end{array}$ & $\begin{array}{c}\text { Even- } \\
2017\end{array}$ & \\
\hline 1 & 1610051802001 & Abdul Aziz Al Fadani & 0.3 & 0.2 & 0.3 & 0.5 & 0.47 \\
\hline 2 & 1610051802002 & Abdurrahman & 0.6 & 0.6 & 0.6 & 0.6 & 0.62 \\
\hline 3 & 1610051802004 & Agung Akhir Syahputra & 0.6 & 0.6 & 0.6 & 0.7 & 0.69 \\
\hline 4 & 1610051802018 & Azmi Rahmat Endardhi & 0.6 & 0.6 & 0.7 & 0.7 & 0.71 \\
\hline 5 & 1610051802019 & Bambang Permadi & 0.7 & 0.7 & 0.8 & 0.8 & 0.78 \\
\hline 6 & 1610051802021 & Bismi & 0.8 & 0.7 & 0.8 & 0.8 & 0.76 \\
\hline 7 & 1610051802024 & Dedy Alfikri & 0.6 & 0.6 & 0.6 & 0.5 & 0.52 \\
\hline 8 & 1610051802055 & Enjel Setia Syahputra & 0.6 & 0.7 & 0.7 & 0.7 & 0.76 \\
\hline 9 & 1610051802058 & Fika Felanda Ardelia & 0.7 & 0.8 & 0.9 & 0.9 & 0.85 \\
\hline 10 & 1610051802059 & Four Putra Aulia & 0.8 & 0.8 & 0.8 & 0.7 & 0.63 \\
\hline 11 & 1610051802040 & Gugus Andri Hermawan & 0.8 & 0.7 & 0.7 & 0.7 & 0.70 \\
\hline 12 & 1610051802041 & Hafizh Nirwanda & 0.5 & 0.5 & 0.6 & 0.6 & 0.64 \\
\hline 13 & 1610051802044 & Indri Febrianti & 0.8 & 0.8 & 0.9 & 0.8 & 0.83 \\
\hline 14 & 1610051802045 & Intan Urfa, Ks & 0.8 & 0.8 & 0.9 & 0.9 & 0.89 \\
\hline 15 & 1610051802046 & Irfansyah & 0.5 & 0.2 & 0.1 & 0.1 & 0.15 \\
\hline 16 & 1610051802047 & Ishad Nasoha & 0.7 & 0.7 & 0.7 & 0.7 & 0.73 \\
\hline 17 & 1610051802051 & Juni Kanasti Dewi & 0.7 & 0.7 & 0.8 & 0.8 & 0.80 \\
\hline 18 & 1610051802052 & Kadek Mirnawati & 0.9 & 0.8 & 0.8 & 0.8 & 0.84 \\
\hline 19 & 1610051802062 & M. Quraish Shihab & 0.7 & 0.8 & 0.8 & 0.8 & 0.80 \\
\hline 20 & 1610051802103 & Santia Tanjung & 0.8 & 0.7 & 0.8 & 0.8 & 0.78 \\
\hline 21 & 1610051802104 & Satrio Wijaksono & 0.6 & 0.6 & 0.7 & 0.7 & 0.73 \\
\hline
\end{tabular}

Table 3. Data Normalization Testing Even Semester-2016 to Odd-2018, with an even-2018 target

\begin{tabular}{ccllcccc}
\hline \multirow{2}{*}{ No } & \multirow{2}{*}{ Student_ID } & \multicolumn{1}{c}{ Student Name } & \multicolumn{4}{c}{ Input } & \multicolumn{2}{c}{ Target } \\
\cline { 4 - 7 } & & & $\begin{array}{c}\text { Even- } \\
\mathbf{2 0 1 6}\end{array}$ & $\begin{array}{c}\text { Odd- } \\
\mathbf{2 0 1 7}\end{array}$ & $\begin{array}{c}\text { Even- } \\
\mathbf{2 0 1 7}\end{array}$ & $\begin{array}{c}\text { Odd- } \\
\mathbf{2 0 1 8}\end{array}$ & $\begin{array}{c}\text { Even- } \\
\mathbf{2 0 1 8}\end{array}$ \\
\hline 22 & 1610051802105 & Sulistiono & 0.44 & 0.57 & 0.40 & 0.43 & 0.44 \\
23 & 1610051802106 & Syukriman Sarza & 0.14 & 0.21 & 0.28 & 0.34 & 0.37 \\
24 & 1610051802107 & Syawiransyah & 0.18 & 0.38 & 0.45 & 0.50 & 0.56 \\
25 & 1610051802108 & Taufik Ramadan Putra & 0.85 & 0.90 & 0.76 & 0.63 & 0.69 \\
26 & 1610051802109 & Teguh Alfalah & 0.38 & 0.45 & 0.51 & 0.55 & 0.55 \\
27 & 1610051802110 & Tri Agustia Ningsih & 0.10 & 0.13 & 0.26 & 0.32 & 0.38 \\
28 & 1610051802114 & Wahhadi Anfar Al Madya & 0.18 & 0.28 & 0.36 & 0.33 & 0.37 \\
29 & 1610051802115 & Wahyu Fadhillah & 0.74 & 0.76 & 0.78 & 0.77 & 0.80 \\
30 & 1610051802125 & Zel Afriadi & 0.29 & 0.40 & 0.46 & 0.46 & 0.48 \\
\hline
\end{tabular}

\section{Designing Artificial Neural Network Architecture}

ANN architecture is presented in Figure 2. ANN consists of Input Layer, Hidden Layer, and Output Layer. In the Input Layer the number of neurons is 4 neurons referring to the number of input variables (ex: Odd-2016, Even-2016, Odd-2017, Even-2017). Output Layer (ex. Odd-2018). The number of neurons assigned is one neuron referring to the time of the prediction made one year later (ex. Odd-2018), and the Hidden Layer number of neurons used is based on trial and error. The activation function used in the hidden layer is the Binary Sigmoid function or the Bipolar Sigmoid function. The activation function in the output 
layer follows the activation function in the previous layer. The best architecture is chosen based on the smallest Mean Square Error (MSE) value from the results of training and network / pattern validation.

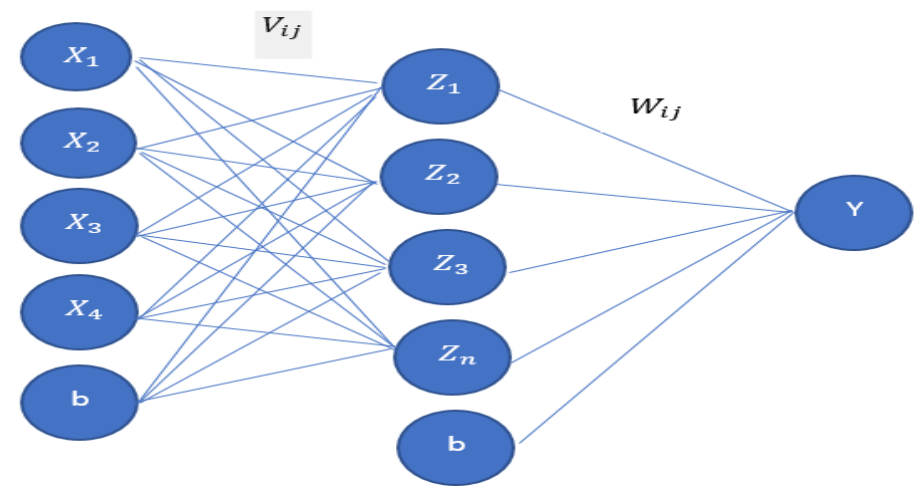

Figure 2. GPA Prediction ANN Architecture

Where: $X_{1}-X_{4}=$ Input Data (Input Layer); $\mathrm{b}=$ Bias; $V_{i j}=$ Weights to Hidden vertices; $W_{i j}=$ Weights to the Output vertices; $Z_{1}-Z_{n}=$ Hidden Layer; $\mathrm{Y}=$ Output Layer.

\section{Multiple Linier Regression (MLR)}

Regression consisting of one independent variable (predictor) and one dependent variable (Response / Criterion) is called simple linear regression (bivariate regression), while regression with more than one independent variable is called multiple regression (multiple regression / multivariate regression), which can consist of of two predictors (multiple regression) or more. This study uses MLR to predict student GPA in the odd semester of 2019, with 1 dependent variable = Even-2018 (Even18) and 5 independent variables $=$ Odd16, Even16, Odd17, Even17, and Odd18. The general form of the Multiple Linear Regression equation is

$$
\mathrm{Y}=\mathrm{a}+b_{1} X_{1}+b_{2} X_{2}+\ldots+b_{n} X_{n}
$$

Where: $\mathrm{Y}=$ Dependent variable; $\mathrm{a}=$ constant; $b_{1} b_{n}=$ Regression coefficient; $X_{1} \ldots X_{n}=$ Independent Variable.

\section{RESULTS AND DISCUSSION}

\section{Backpropagation Neural Network (BNN) Algorithm}

\section{ANN Training and Testing}

The training and testing of backpropagation ANN are implemented in 8 architectural models. Prior to training and testing, the network parameter settings must be determined to obtain optimal results.

Network parameters include (Table 4): learning rate, constant momentum (mc), maximum epoch, and goal value (error tolerance).

Table 4. Architectural Model and Training Parameters

\begin{tabular}{cccccccc}
\hline No & $\begin{array}{c}\text { Input } \\
\text { Layer }\end{array}$ & $\begin{array}{c}\text { Hidden } \\
\text { Layer }\end{array}$ & Output Layer & $\begin{array}{c}\text { Learning } \\
\text { Rate }\end{array}$ & $\begin{array}{c}\text { Momentum } \\
\text { Constant }\end{array}$ & Epoch & Goal \\
\hline 1 & 4 & 3 & 1 & 0.1 & 0.5 & 10000 & 0.001 \\
2 & 4 & 5 & 1 & 0.1 & 0.5 & 10000 & 0.001 \\
3 & 4 & 8 & 1 & 0.1 & 0.5 & 10000 & 0.001 \\
4 & 4 & 10 & 1 & 0.1 & 0.5 & 10000 & 0.001 \\
5 & 4 & 15 & 1 & 0.1 & 0.5 & 10000 & 0.001 \\
6 & 4 & 20 & 1 & 0.1 & 0.5 & 10000 & 0.001 \\
7 & 4 & 23 & 1 & 0.1 & 0.5 & 10000 & 0.001 \\
8 & 4 & 25 & 1 & 0.1 & 0.5 & 10000 & 0.001 \\
\hline
\end{tabular}




\section{Test Result}

Based on Table 4, this study uses 8 architectures. For example, Architecture 1 consists of 4 input layers, 3 hidden layers and 1 output layer, with a time of 7 seconds, epoch 2307, MSE during training 0.00099998 and MSE during validation 0.015763 . Comparison of the test results of 8 network architecture models, MSE at the time of training and MSE at the time of validation is presented in Table 5.

Table 5. The results of the comparison of the training architecture model and validation

\begin{tabular}{|c|c|c|c|c|c|}
\hline \multirow{3}{*}{ No } & \multirow{3}{*}{ Architecture } & \multicolumn{4}{|c|}{ Backpropagation Neural Network (BNN) } \\
\hline & & \multicolumn{3}{|c|}{ Training } & \multirow{2}{*}{$\frac{\text { Validation }}{\text { MSE }}$} \\
\hline & & Time (sec) & Epoch & $M S E$ & \\
\hline 1 & $4-3-1$ & 7 & 2307 & 0.00099998 & 0.015763 \\
\hline 2 & $4-5-1$ & 0 & 102 & 0.00099532 & 0.0038793 \\
\hline 3 & $4-8-1$ & 0 & 345 & 0.00099943 & 0.011499 \\
\hline 4 & $4-10-1$ & 0 & 236 & 0.00099919 & 0.0061488 \\
\hline 5 & $4-15-1$ & 4 & 1440 & 0.00099949 & 0.065083 \\
\hline 6 & $4-20-1$ & 3 & 1037 & 0.00099971 & 0.011863 \\
\hline 7 & $4-23-1$ & 1 & 503 & 0.00099992 & 0.094984 \\
\hline 8 & $4-25-1$ & 1 & 816 & 0.00099999 & 0.045816 \\
\hline
\end{tabular}

From the 8 architectures that have, the smallest MSE value both during training and during network validation (pattern), is the 4-5-1 architecture. Architecture 4-5-1, MSE at training $=0.00099965532$ and MSE during network validation $=0.0038793$ with an epoch of 102 iterations (Figure 3).

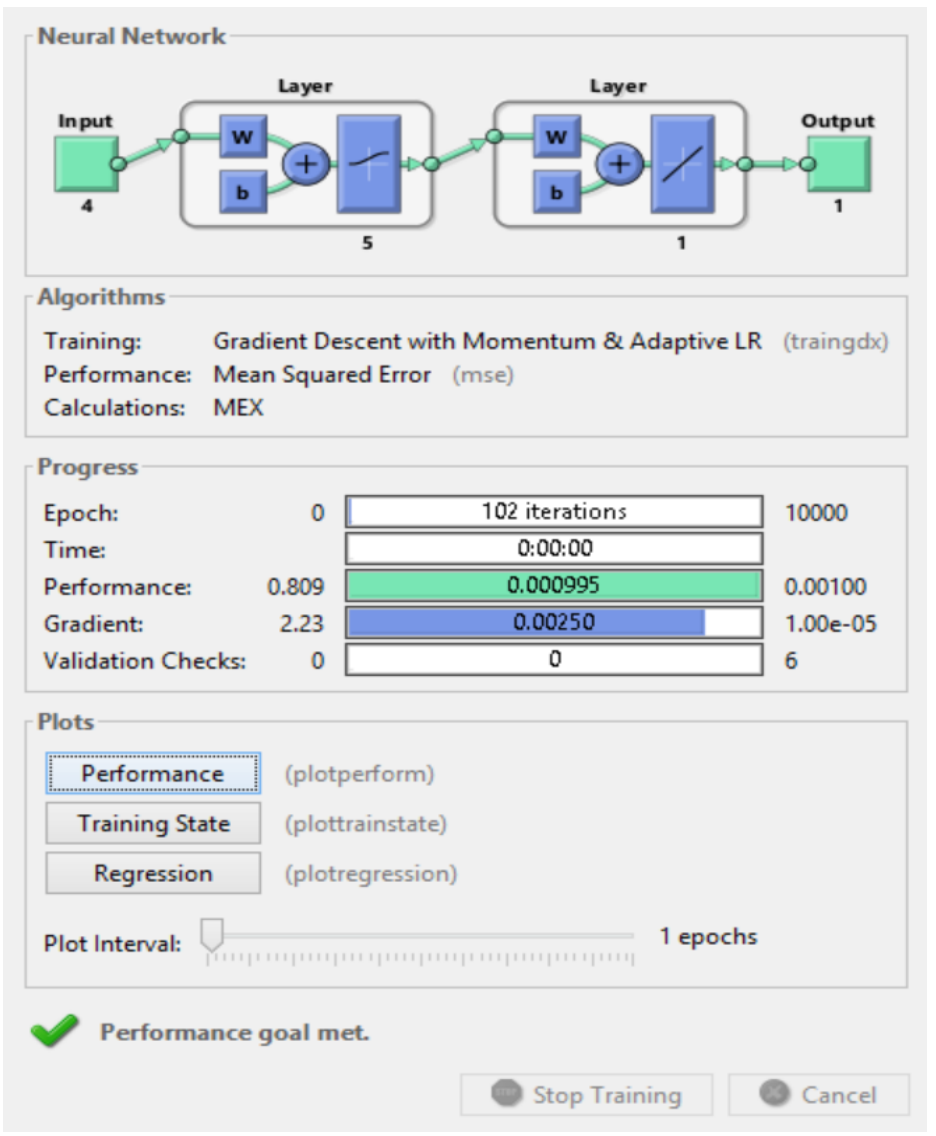

Figure 3. Training data with the 4-5-1 architectural model

Figure 3 shows that the best training performance is 0.00099532 at epoch 102.The results of the training process with the best model performance produced by the 4-5-1 architecture, with an epoch that occurs at 102 iterations, is shown in Figure 4. 


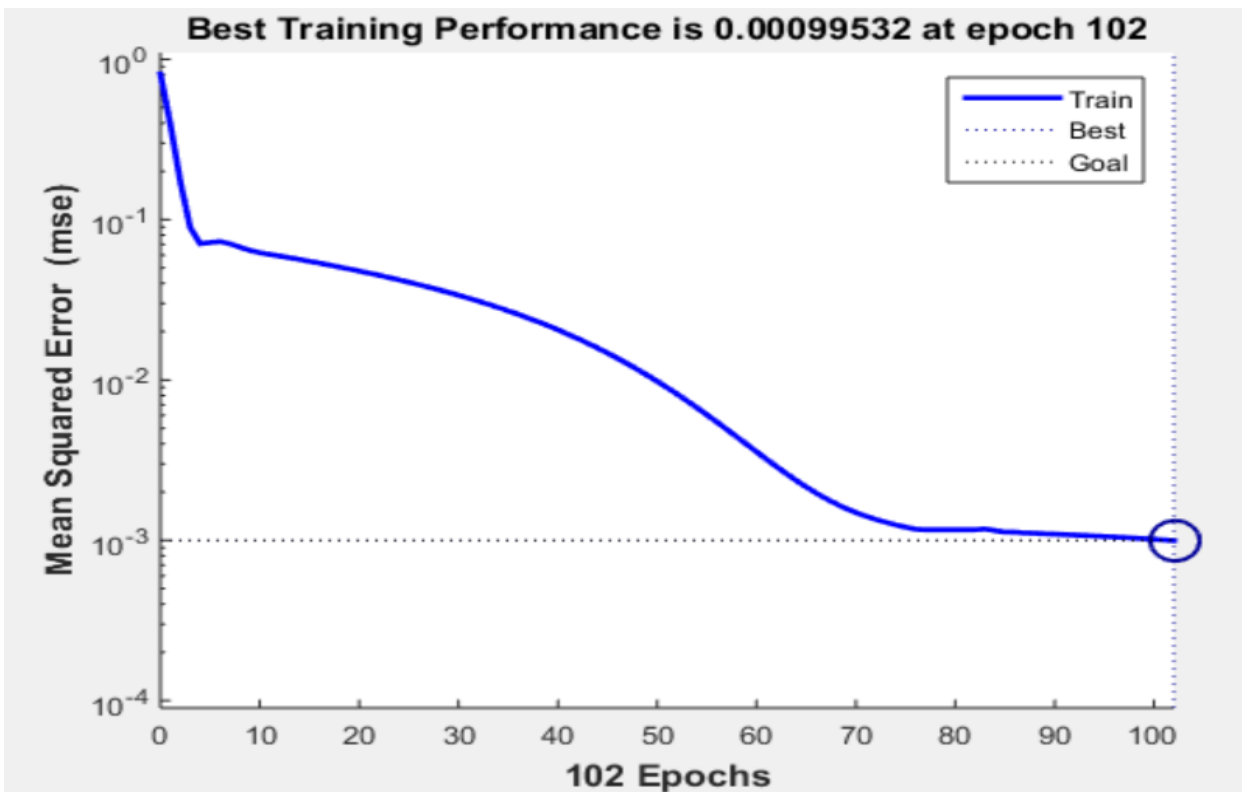

Figure 4. Best training performance with 4-5-1 architecture

Architecture 4-5-1 shows the result, that the value at the output of the ANN is close to the same result as the target. There is a difference (gap) in pattern 10 (Sample 10). The graph of the ANN output and the target in the Training Data with a Mean Square Error (MSE) of 0.00099532 from the 21 samples is presented in Figure 5.

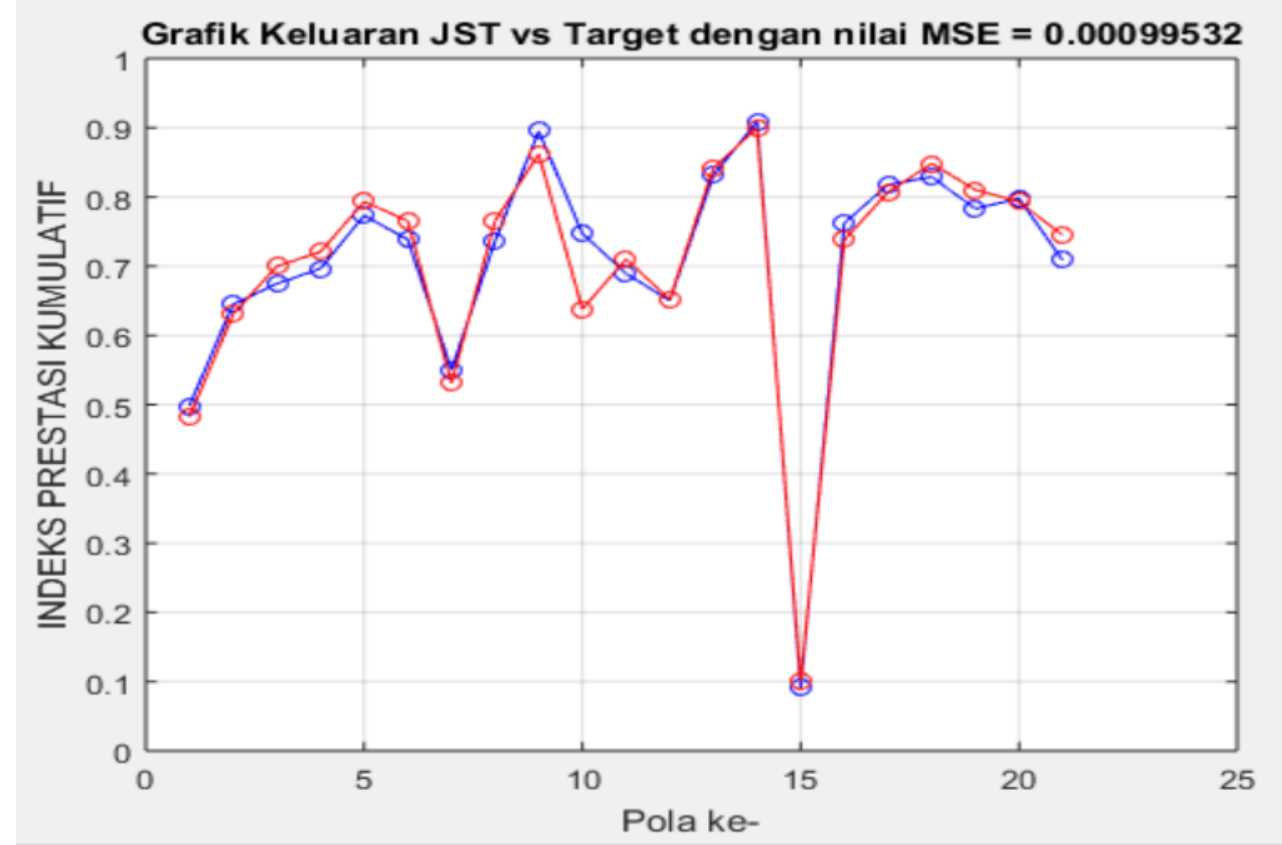

Figure 5. ANN Output vs Target Data Training

The ANN output graph and the target on the testing data of 9 samples with a Mean Square Error (MSE) of 0.0038739 are presented in Figure 6. The ANN output value and the target value are close to the same in the 3rd pattern (Data sample 3) 


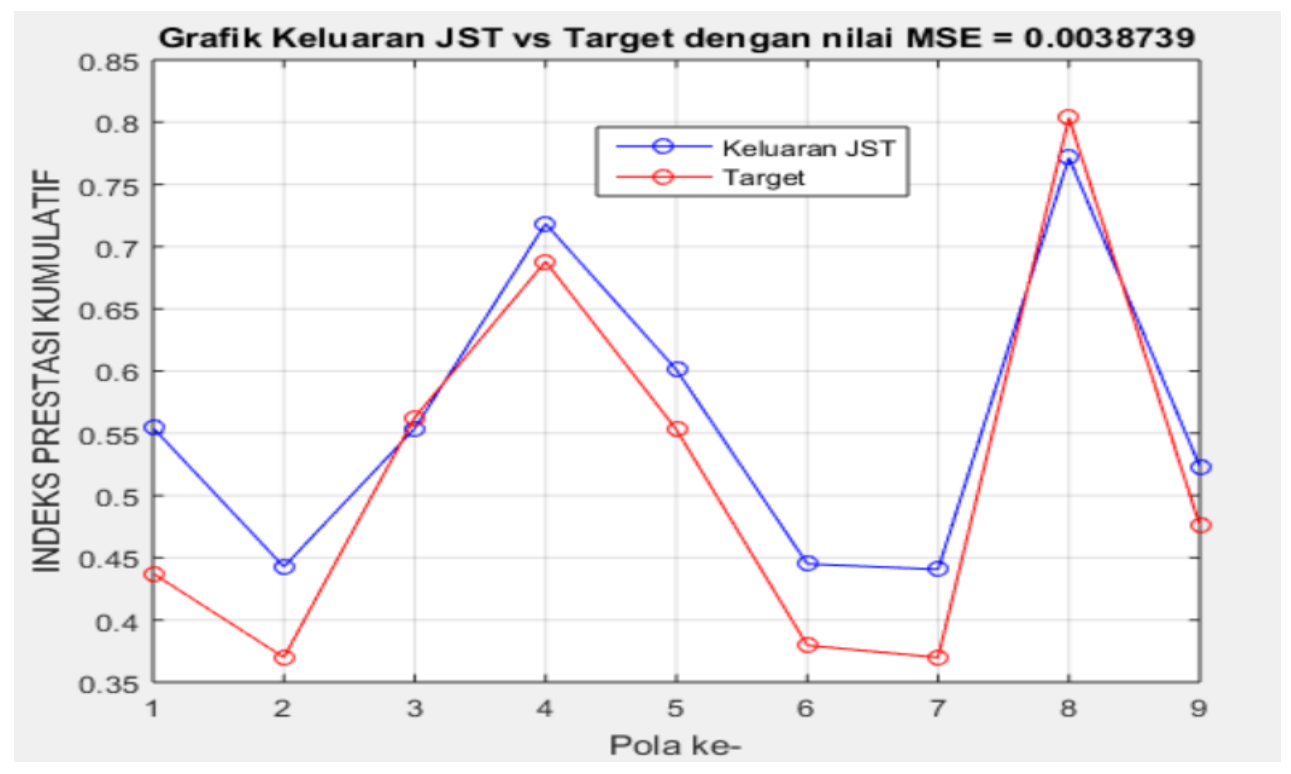

Figure 6. ANN output vs target network validation on training data

Sample data from 1 to 21 is training data used to test the best architectural models (i.e. architecture 4-5-1). The target value is obtained from the previous training data normalization process. Output is obtained using Matlab from input data and target data from Training Data, Error Value is obtained from: Target Value - Output Value, SSE Value = Error Result is raised to a power of 2. The number of SSE is obtained from the total SSE value. MSE value = Total SSE value / 21 (number of data). The result will be 1 (True) if the value of SSE $<=0.01$. The value 0.01 is the minimum error used. The accuracy value $(\%)$ is obtained from: Total Correct / $21 * 100$.The best architectural model of the 8 models is used to check the accuracy of the 4-5-1 model with 102 iteration epochs are presented in Table 6.

Table 6. The level of accuracy of training data with the 4-5-1 architectural model

\begin{tabular}{cccrcc}
\hline Data & Target Value & $\begin{array}{c}\text { Output } \\
\text { Value }\end{array}$ & Error Value & SSE Value & Accuracy Results \\
\hline 1 & 0.47 & 0.4848 & -0.0148 & 0.00021904 & 1 \\
2 & 0.62 & 0.6299 & -0.0099 & 0.00009801 & 1 \\
3 & 0.69 & 0.6788 & 0.0112 & 0.00012544 & 1 \\
4 & 0.71 & 0.7160 & -0.0060 & 0.00003600 & 1 \\
5 & 0.78 & 0.7841 & -0.0041 & 0.00001681 & 1 \\
6 & 0.76 & 0.7585 & 0.0015 & 0.00000225 & 1 \\
7 & 0.52 & 0.5468 & -0.0268 & 0.00071824 & 1 \\
8 & 0.76 & 0.7525 & 0.0075 & 0.00005625 & 1 \\
9 & 0.85 & 0.8743 & -0.0243 & 0.00059049 & 1 \\
10 & 0.63 & 0.7477 & -0.1177 & 0.01385329 & 0 \\
11 & 0.70 & 0.6734 & 0.0266 & 0.00070756 & 1 \\
12 & 0.64 & 0.6756 & -0.0356 & 0.00126736 & 1 \\
13 & 0.83 & 0.8414 & -0.0114 & 0.00012996 & 1 \\
14 & 0.89 & 0.8924 & -0.0024 & 0.00000576 & 1 \\
15 & 0.15 & 0.0973 & 0.0527 & 0.00277729 & 1 \\
16 & 0.73 & 0.7637 & -0.0337 & 0.00113569 & 1 \\
17 & 0.80 & 0.8126 & -0.0126 & 0.00015876 & 1 \\
18 & 0.84 & 0.7827 & 0.0573 & 0.00328329 & 1 \\
19 & 0.80 & 0.8206 & -0.0206 & 0.00042436 & 1 \\
20 & 0.78 & 0.7750 & 0.0050 & 0.00002500 & 1 \\
21 & 0.74 & 0.7263 & 0.0137 & 0.00018769 & 1 \\
\hline & & & Sum $\mathbf{~ o f ~ S S E}$ & $\mathbf{0 . 0 2 5 8 1 8 5 4}$ & $\mathbf{9 5 . 2 3 \%}$
\end{tabular}

Based on Figure 7 and Table 6 where the target and output of ANN (prediction results) were analyzed by linear regression using postreg on Scilab. The correlation coefficient is 0.9998 , close to 1 . This 
shows good results for the match between network output (ANN) and the target. Compared with the results of training the correlation value of the test data is smaller than the training data. The architecture used to predict the 2019 Odd GPA is the architecture on the test data. The weights and biases used in the test data are weights and bias in the training data.

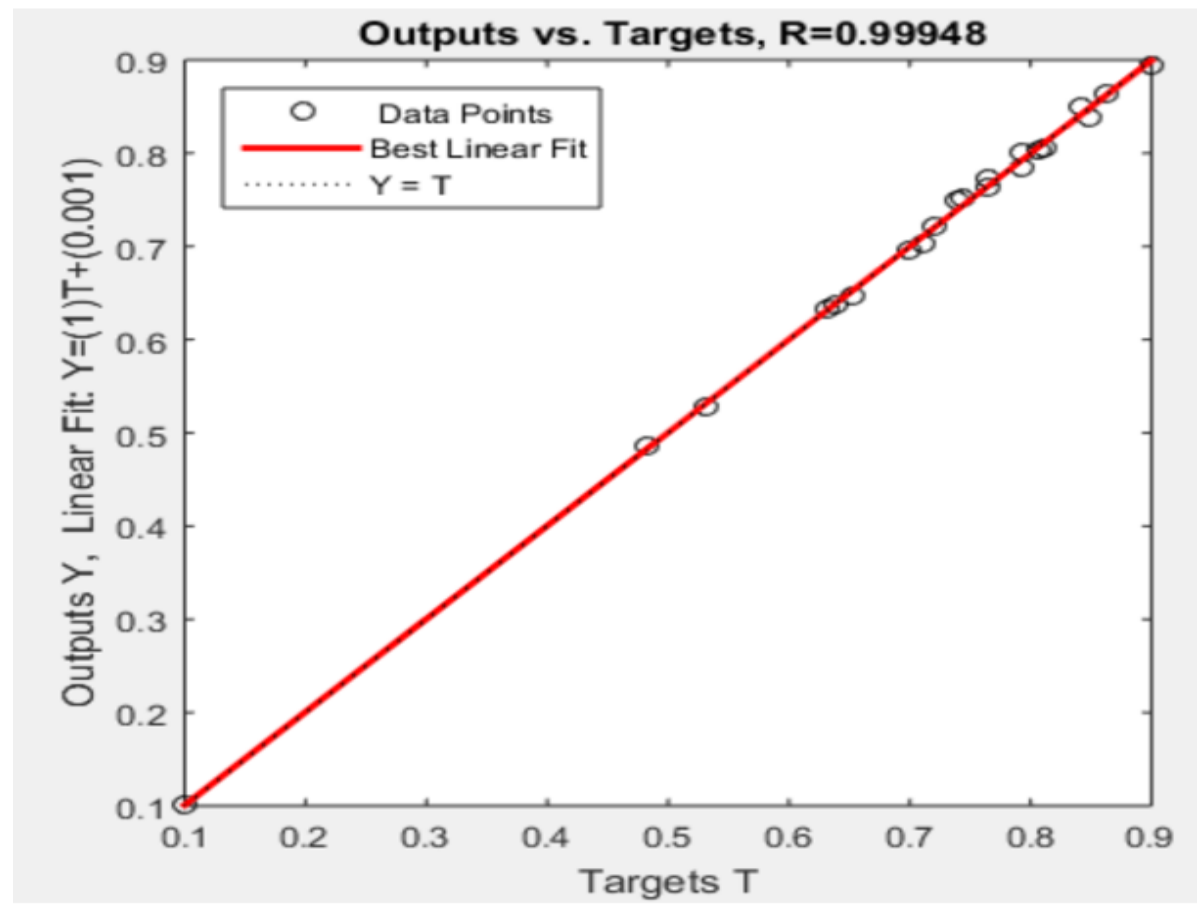

Figure 7. Graph of test data results

Table 7 presents the results of the predicted GPA of students in the odd semester of 2019, real data is obtained from the 2018 GPA. Targets are obtained from testing data after normalization and prediction targets are obtained from the calculation output in Matlab using equation (3):

$\frac{(\text { TargetPrediksi-0.1 }) *\left(\max \_D a t a R e a l-\min \_ \text {DataReal }\right)}{0.8}+\min \_$DataReal

Table 7. Prediction of Odd GPA in 2019

\begin{tabular}{clcccc}
\hline \multicolumn{5}{c}{ Prediction of Odd GPA in 2019 } \\
\hline \multirow{2}{*}{ Data } & \multicolumn{1}{c}{ Student Name } & Target Value & Target & Predicted Target & $\begin{array}{c}\text { GPA } \\
\text { Prediction }\end{array}$ \\
\hline 22 & Sulistiono & 3.30 & 0.44 & 0.4631 & 3.32 \\
23 & Syukriman Sarza & 3.23 & 0.37 & 0.5343 & 3.39 \\
24 & Syawiransyah & 3.43 & 0.56 & 0.6535 & 3.52 \\
25 & Taufik Ramadan Putra & 3.56 & 0.69 & 0.6006 & 3.47 \\
26 & Teguh Alfalah & 3.42 & 0.55 & 0.6622 & 3.53 \\
27 & Tri Agustia Ningsih & 3.24 & 0.38 & 0.5413 & 3.40 \\
28 & Wahhadi Anfar Al Madya & 3.23 & 0.37 & 0.5553 & 3.42 \\
29 & Wahyu Fadhillah & 3.68 & 0.80 & 0.7926 & 3.67 \\
30 & Zel Afriadi & 3.34 & 0.48 & 0.6363 & 3.50 \\
\hline
\end{tabular}

\section{Multiple Linier Regression}

\section{Data Used}

The data used in predicting the 2019 Odd semester GPA is presented in Table 1. Then calculating the value of each variable in the matrix $\mathrm{A}, \mathrm{b}$ and $\mathrm{H}$, where $\mathrm{A} \mathrm{xb}=\mathrm{H}$. When the free variable is more than 2, the constant value and regression variable each independent variable can be obtained using a determinant matrix [2]. 
$A=\left(\begin{array}{cccccc}N & \Sigma X 1 & \Sigma X 2 & \Sigma X 3 & \Sigma X 4 & \Sigma X 5 \\ \Sigma X 1 & \Sigma(X 1 X 1) & \Sigma(X 1 X 2) & \Sigma(X 1 X 3) & \Sigma(X 1 X 4) & \Sigma(X 1 X 5) \\ \Sigma X 2 & \Sigma(X 2 X 1) & \Sigma(X 2 X 2) & \Sigma(X 2 X 3) & \Sigma(X 2 X 4) & \Sigma(X 2 X 5) \\ \Sigma X 3 & \Sigma(X 3 X 1) & \Sigma(X 3 X 2) & \Sigma(X 3 X 3) & \Sigma(X 3 X 4) & \Sigma(X 3 X 5) \\ \Sigma X 4 & \Sigma(X 4 X 1) & \Sigma(X 4 X 2) & \Sigma(X 4 X 3) & \Sigma(X 4 X 4) & \Sigma(X 4 X 5) \\ \Sigma X 5 & \Sigma(X 5 X 1) & \Sigma(X 5 X 2) & \Sigma(X 5 X 3) & \Sigma(X 5 X 4) & \Sigma(X 5 X 5)\end{array}\right)$

$H=\left(\begin{array}{l}\Sigma \mathbf{Y} \\ \Sigma(\mathbf{X 1 Y}) \\ \Sigma(\mathbf{X 2 Y}) \\ \Sigma(\mathbf{X 3 Y}) \\ \Sigma(\mathbf{X 4 Y}) \\ \Sigma(\mathbf{X 5 Y})\end{array}\right)=\left(\begin{array}{r}97.24 \\ 305.47 \\ 303.88 \\ 313.36 \\ 315.60 \\ 316.67\end{array}\right)$

$A=\left(\begin{array}{c|c|c|c|c|c|}30 & 93.46 & 92.31 & 95.04 & 95.68 & 96.02 \\ \hline 93.46 & 294.67 & 291.57 & 299.89 & 301.3 & 301.96 \\ \hline 92.31 & 291.57 & 290.13 & 298.68 & 299.94 & 300.52 \\ \hline 95.04 & 299.89 & 298.68 & 307.71 & 309.15 & 309.84 \\ \hline 95.68 & 301.3 & 299.94 & 309.15 & 311.1 & 311.93 \\ \hline 96.02 & 301.96 & 300.52 & 309.84 & 311.93 & 312.91 \\ \hline\end{array}\right.$

Table 8. Value Determinant Matrix

\begin{tabular}{|c|c|c|}
\hline No & Matrik & $\begin{array}{c}\text { Nilai } \\
\text { Determinat }\end{array}$ \\
\hline 1 & $\mathrm{~A}$ & 0.52837 \\
\hline 2 & $\mathrm{~A} 0$ & 0.03898 \\
\hline 3 & $\mathrm{~A} 1$ & 0.02932 \\
\hline 4 & $\mathrm{~A} 2$ & -0.1241 \\
\hline 5 & $\mathrm{~A} 3$ & 0.03187 \\
\hline 6 & $\mathrm{~A} 4$ & -0.08364 \\
\hline 7 & $\mathrm{~A} 5$ & 0.66548 \\
\hline
\end{tabular}

From the equation $\mathrm{A} x \mathrm{~b}=\mathrm{H}$, we will obtain the matrix values (i.e. A0, A1, A2, A3, A4 and A5) and the determinant values of $\operatorname{Det}(\mathrm{A} 0)$, Det (A1), Det (A2), Det (A3), Det (A4) and Det (A5), as presented in Table 8. Next, the values of a, b1, b2, b3, b4, and b5 will be calculated using the formula a $=\frac{\operatorname{Det}(A 0)}{\operatorname{Det}(A)}, \mathrm{b} 1=\frac{\operatorname{Det}(A 1)}{\operatorname{Det}(A)}$, $\mathrm{b} 2=\frac{\operatorname{Det}(A 2)}{\operatorname{Det}(A)}, \mathrm{b} 3=\frac{\operatorname{Det}(A 3)}{\operatorname{Det}(A)}, \mathrm{b} 4=\frac{\operatorname{Det}(A 4)}{\operatorname{Det}(A)}$, and $\mathrm{b} 5=\frac{\operatorname{Det}(A 5)}{\operatorname{Det}(A)}$. The results are as below:

$$
b=\left(\begin{array}{c}
a \\
b 1 \\
b 2 \\
b 3 \\
b 4 \\
b 5
\end{array}\right)=\left(\begin{array}{c}
0.0738 \\
0.0555 \\
-0.2349 \\
0.0603 \\
-0.1583 \\
1.25948
\end{array}\right)
$$

Then the resulting linear regression equation in this problem is $\mathrm{Y}=\mathrm{a}+\mathrm{b} 1 \mathrm{X} 1+\mathrm{b} 2 \mathrm{X} 2+\mathrm{b} 3 \mathrm{X} 3+$ $\mathrm{b} 4 \mathrm{X} 4+\mathrm{b} 5 \mathrm{X} 5=0.0738+0.0555 * \mathrm{X} 1-0.2349 * \mathrm{X} 2+0.0603 * \mathrm{X} 3-0.1583 * \mathrm{X} 4+1.25948 * \mathrm{X} 5$.

Where: $\mathrm{X} 1=$ independent variable $1, \mathrm{X} 2=$ independent variable $2, \mathrm{X} 3=$ free variable $3, \mathrm{X} 4=$ independent variable 4 and X5 = independent variable 5. The data in the table were tested using Matlab, the results are presented in Figure 8. Based on the graph presented In Figure 8, the prediction results are compared with the target.

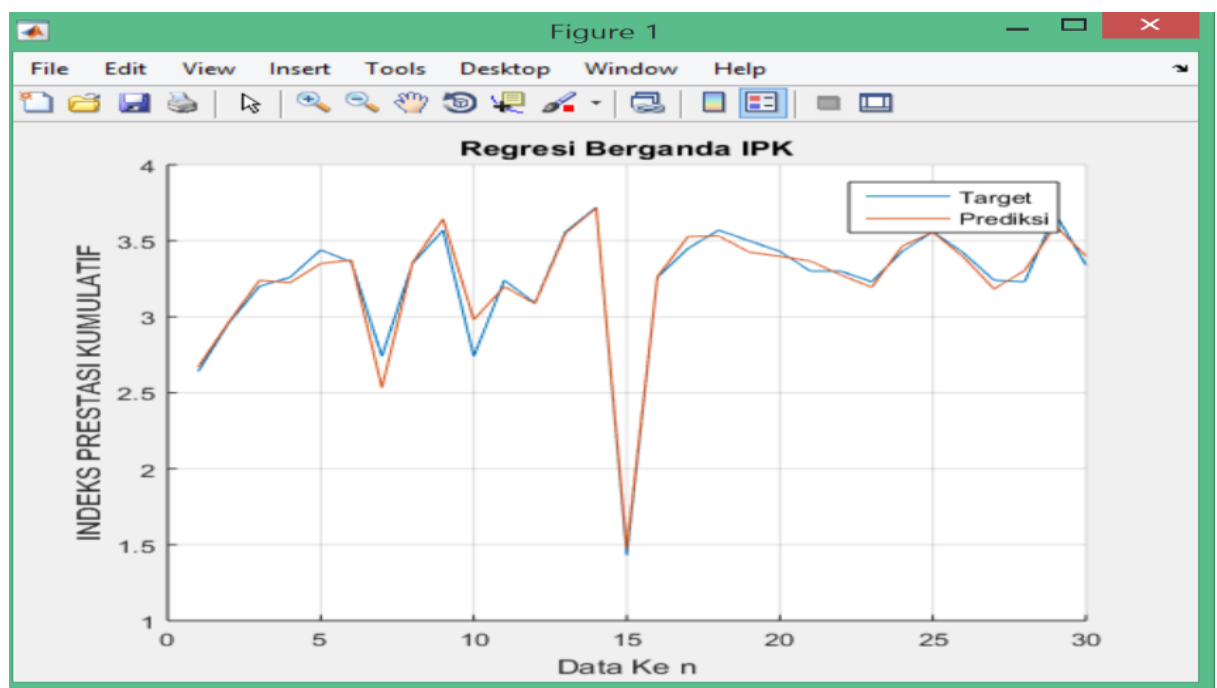

Figure 8. Graph of prediction results vs target GPA

Table 9 presents the predicted results of the student's GPA for 2019 Odd Semester (Odd19), using MLR. 
Table 9. Prediction results of GPA using MLR

\begin{tabular}{|c|c|c|c|c|c|c|c|c|c|}
\hline \multirow[b]{2}{*}{ No } & \multirow[b]{2}{*}{ Student_ID } & \multirow[b]{2}{*}{ Student Name } & \multicolumn{5}{|c|}{ Input } & \multirow{2}{*}{$\begin{array}{c}\text { Target } \\
\text { Even- } \\
2018\end{array}$} & \multirow{2}{*}{$\frac{\text { Prediction }}{\text { Odd-2019 }}$} \\
\hline & & & $\begin{array}{l}\text { Odd- } \\
2016\end{array}$ & $\begin{array}{l}\text { Even- } \\
2016\end{array}$ & $\begin{array}{l}\text { Odd- } \\
2017\end{array}$ & $\begin{array}{l}\text { Even- } \\
2017 \\
\end{array}$ & $\begin{array}{l}\text { Odd- } \\
2018\end{array}$ & & \\
\hline 1 & 1610051802001 & Abdul Aziz Al Fadani & 1.99 & 1.76 & 1.93 & 2.34 & 2.49 & 2.64 & 2.65 \\
\hline 2 & 1610051802002 & Abdurrahman & 2.86 & 2.80 & 2.86 & 2.90 & 2.92 & 2.96 & 2.97 \\
\hline 3 & 1610051802004 & Agung Akhir Syahputra & 2.88 & 2.78 & 2.97 & 3.07 & 3.12 & 3.20 & 3.20 \\
\hline 4 & 1610051802018 & Azmi Rahmat Endardhi & 2.82 & 2.93 & 3.10 & 3.12 & 3.18 & 3.26 & 3.24 \\
\hline 5 & 1610051802019 & Bambang Permadi & 3.26 & 3.26 & 3.33 & 3.34 & 3.39 & 3.44 & 3.43 \\
\hline 6 & 1610051802021 & Bismi & 3.37 & 3.21 & 3.33 & 3.31 & 3.31 & 3.36 & 3.35 \\
\hline 7 & 1610051802024 & Dedy Alfikri & 2.74 & 2.76 & 2.76 & 2.56 & 2.63 & 2.74 & 2.65 \\
\hline 8 & 1610051802055 & Enjel Setia Syahputra & 3.01 & 3.06 & 3.20 & 3.27 & 3.31 & 3.35 & 3.37 \\
\hline 9 & 1610051802058 & Fika Felanda Ardelia & 3.16 & 3.47 & 3.59 & 3.64 & 3.59 & 3.57 & 3.60 \\
\hline 10 & 1610051802059 & Four Putra Aulia & 3.40 & 3.55 & 3.48 & 3.16 & 2.94 & 2.74 & 2.84 \\
\hline 11 & 1610051802040 & Gugus Andri Hermawan & 3.33 & 3.04 & 3.09 & 3.14 & 3.15 & 3.24 & 3.20 \\
\hline 12 & 1610051802041 & Hafizh Nirwanda & 2.58 & 2.66 & 2.89 & 2.91 & 2.98 & 3.09 & 3.06 \\
\hline 13 & 1610051802044 & Indri Febrianti & 3.54 & 3.51 & 3.64 & 3.54 & 3.53 & 3.56 & 3.55 \\
\hline 14 & 1610051802045 & Intan Urfa, Ks & 3.54 & 3.51 & 3.63 & 3.70 & 3.70 & 3.72 & 3.74 \\
\hline 15 & 1610051802046 & Irfansyah & 2.70 & 1.66 & 1.45 & 1.59 & 1.58 & 1.45 & 1.66 \\
\hline 16 & 1610051802047 & Ishad Nasoha & 3.14 & 3.20 & 3.25 & 3.27 & 3.23 & 3.26 & 3.24 \\
\hline 17 & 1610051802051 & Juni Kanasti Dewi & 3.13 & 3.25 & 3.34 & 3.47 & 3.43 & 3.45 & 3.46 \\
\hline 18 & 1610051802052 & Kadek Mirnawati & 3.61 & 3.39 & 3.45 & 3.51 & 3.55 & 3.57 & 3.60 \\
\hline 19 & 1610051802062 & M. Quraish Shihab & 3.07 & 3.33 & 3.50 & 3.40 & 3.44 & 3.50 & 3.47 \\
\hline 20 & 1610051802103 & Santia Tanjung & 3.39 & 3.28 & 3.31 & 3.39 & 3.39 & 3.45 & 3.42 \\
\hline 21 & 1610051802104 & Satrio Wijaksono & 2.89 & 2.91 & 3.12 & 3.21 & 3.25 & 3.30 & 3.32 \\
\hline 22 & 1610051802105 & Sulistiono & 3.25 & 3.30 & 3.44 & 3.26 & 3.29 & 3.30 & 3.31 \\
\hline 23 & 1610051802106 & Syukriman Sarza & 3.01 & 2.99 & 3.06 & 3.14 & 3.20 & 3.23 & 3.26 \\
\hline 24 & 1610051802107 & Syawiransyah & 3.16 & 3.03 & 3.24 & 3.31 & 3.36 & 3.43 & 3.44 \\
\hline 25 & 1610051802108 & Taufik Ramadan Putra & 3.74 & 3.73 & 3.78 & 3.63 & 3.50 & 3.56 & 3.47 \\
\hline 26 & 1610051802109 & Teguh Alfalah & 3.12 & 3.24 & 3.31 & 3.38 & 3.42 & 3.42 & 3.46 \\
\hline 27 & 1610051802110 & Tri Agustia Ningsih & 3.18 & 2.95 & 2.98 & 3.12 & 3.18 & 3.24 & 3.25 \\
\hline 28 & 1610051802114 & Wahhadi Anfar & 3.09 & 3.03 & 3.14 & 3.22 & 3.19 & 3.23 & 3.23 \\
\hline 29 & 1610051802115 & Wahyu Fadhillah & 3.54 & 3.61 & 3.63 & 3.66 & 3.65 & 3.68 & 3.66 \\
\hline 30 & 1610051802125 & Zel Afriadi & 3.16 & 3.13 & 3.26 & 3.32 & 3.32 & 3.34 & 3.37 \\
\hline
\end{tabular}

\section{Accuracy Calculation}

The calculation of accuracy in predicting a student's GPA in the odd semester of 2019 at STMIK

Amik Riau is done using Mean Square Error (MSE). MSE is a calculation of the amount of predictive data with actual data (Results are presented in Table 10). The MSE equation is as follows:

$$
\mathrm{MSE}=\frac{\sum_{t=1}^{n}(X t-F t)^{2}}{n}
$$

Where $n=$ the amount of data; $X t=$ actual period data $t ; F t=$ forecast value for period $\mathrm{t}$

Table 10. Actual calculations and predictions

\begin{tabular}{cccrc}
\hline Data & $X t$ & $F t$ & $(X t-F t)$ & $(X t-F t)^{2}$ \\
\hline 1 & 2.64 & 2.67 & 0.03 & 0.00090000 \\
2 & 2.96 & 2.97 & 0.01 & 0.00010000 \\
3 & 3.20 & 3.20 & 0.00 & 0.00000000 \\
4 & 3.26 & 3.24 & -0.02 & 0.00040000 \\
5 & 3.44 & 3.43 & -0.01 & 0.00010000 \\
6 & 3.36 & 3.35 & -0.01 & 0.00010000 \\
7 & 2.74 & 2.65 & -0.09 & 0.00810000 \\
8 & 3.35 & 3.37 & 0.02 & 0.00040000 \\
9 & 3.57 & 3.60 & 0.03 & 0.00090000 \\
10 & 2.74 & 2.84 & 0.10 & 0.01000000 \\
11 & 3.24 & 3.20 & -0.04 & 0.00160000 \\
12 & 3.09 & 3.06 & -0.03 & 0.00010000 \\
13 & 3.56 & 3.55 & -0.01 & 0.00040000 \\
14 & 3.72 & 3.74 & 0.02 & 0.04410000 \\
15 & 1.45 & 1.66 & 0.21 & 0.00040000 \\
16 & 3.26 & 3.24 & -0.02 & 0.00010000 \\
17 & 3.45 & 3.46 & 0.01 & 0.00090000 \\
18 & 3.57 & 3.60 & 0.03 & 0.00090000 \\
19 & 3.50 & 3.47 & -0.03 & 0.00090000 \\
20 & 3.45 & 3.42 & -0.03 & 0.00040000 \\
21 & 3.30 & 3.32 & 0.02 & 0.00010000 \\
22 & 3.30 & 3.31 & 0.01 & 0.00090000 \\
23 & 3.23 & 3.26 & 0.03 & 0.00010000 \\
24 & 3.43 & 3.44 & 0.01 & 0.00810000 \\
25 & 3.56 & 3.47 & -0.09 & 0.00160000 \\
26 & 3.42 & 3.46 & 0.04 & 0.00010000 \\
27 & 3.24 & 3.25 & 0.01 &
\end{tabular}




\begin{tabular}{rrrrr}
28 & 3.23 & 3.23 & 0.00 & 0.00000000 \\
29 & 3.68 & 3.66 & -0.02 & 0.00040000 \\
30 & 3.34 & 3.37 & 0.03 & 0.00090000 \\
\hline & & & Total & 0.08390000 \\
\cline { 3 - 4 } & & &
\end{tabular}

So that MSE $=\frac{0.08390000}{30}=0.00279666667=0.27966667 \%$ with the Multiple Correlation coefficient (R):

$$
\begin{aligned}
& \mathrm{R}=\frac{b 1 \sum X 1 Y+b 2 \Sigma X 2 Y+b 3 \sum X 3 Y+b 4 \Sigma X 4 Y+b 5 \sum X 5 Y}{\Sigma Y^{2}} \\
& \mathrm{R}=\frac{313.3581019}{320.5734}=0.9774925
\end{aligned}
$$

The coefficient of determination $\left(R^{2}\right)=0.95549159$. If the Coefficient of Determination $\left(R^{2}\right)$ is greater (close to 1), the more accurate the prediction is made. Thus, the prediction of student GPA using MLR is accurate, because the result of the coefficient of determination $\left(R^{2}\right)$ is close to 1 (one), namely = 0.9774925 .

\section{CONCLUSION}

From the results of the BNN and MLR testing, it can be applied to predict the 2019 Odd semester Student GPA through training and testing of past data using Matlab software. The BNN algorithm is implemented in 8 architectural models (i.e. 4-3-1, 4-5-1, 4-8-1, 4-10-1, 5-15-1,4-20-1, 4-23-1 and 4-25-1). From the 8 architectures, the 4-5-1 model has the smallest MSE in both training and testing. Architectural Model 4-5-1, MSE during training $=0.00099965532$ and MSE during network validation $=0.0038793$ with an epoch of 102 iterations and the resulting accuracy value of $95.24 \%$. From the test using the correlation coefficient is 0.99948 , close to 1 . This shows good results for the compatibility of network output (ANN) with the target.

The level of accuracy at the BNN during training and testing is influenced by the amount of data used. Meanwhile, the number of neurons in the hiiden layer does not have a significant effect on the level of network accuracy (model). Predicting student GPA using MLR can be concluded that: the data used to predict the GPA is the data of the 2016 Amik Riau STMIK Student, and the calculation of the prediction in the odd semester of 2019, the highest value is on the 29th data with a GPA of 3.60 and the lowest score is on the 15th data with GPA of 1.47. After testing the MLR algorithm using MSE, a value of $0.27966667 \%$ was obtained, with a multiple correlation coefficient $(\mathrm{R})$ of $\mathrm{R}=0.9774925$ and a coefficient of determination $\left(R^{2}\right)=0.95549159$. If the value of $R^{2}$ is greater or closer to one, the more accurate the prediction will be. Thus the prediction of student GPA using MLR is accurate, because the value of the coefficient of determination $\left(\mathrm{R}^{2}\right)$ is close to 1 (one).

To get better results on the BNN and MLR algorithms, further research is needed using a larger number of input variables. The initialized weight value of the BNN algorithm is better because its value greatly affects the output results of the testing data. The R2 value on the MLR will increase if the number of independent variables / predictors entered in the regression equation and the sample size is increased (more). 


\section{REFERENCES}

A. Wanto, M. Zarlis, Sawaluddin, D. Hartama, J. Tata Hardinata, and H. F. Silaban (2017), "Analysis of Artificial Neural Network Backpropagation Using Conjugate Gradient Fletcher Reeves In The Predicting Process," Journal of Physics: Conference Series, vol. 930, no. 1, pp. 1-7. doi :10.1088/1742-6596/930/1/012018

Darling-Hammond, L., Flook, L., Cook-Harvey, C., Barron, B., Osher, D., (2019). Implications for educational practice of the science of learning and development. Applied Developmental Science, pp. 1-44. https://doi.org/10.1080/10888691.2018.1537791

Herdianto. (2013). Prediksi Kerusakan Motor Induksi Menggunakan Metode Jaringan Saraf Tiruan Backpropagation. Universitas Sumatera Utara.

Izzah, Abidatul and Widyastuti, R. (2017). Prediksi Harga Saham Menggunakan Improved Multiple Linear Regression untuk Pencegahan Data Outlier. Kinetik, 2(3), 141-149. https://doi.org/10.22219/kinetik.v2i3.268

J. Syed, R. U. Baig, S. Algarni, Y. V. V. S. Murthy, M. Masood, and M. Inamurrahman(2017), “Artificial Neural Network modeling of a hydrogen dual fueled diesel engine characteristics: An experiment approach," International Journal of Hydrogen Energy, vol. 42, no. 21, pp. 14750-14774. https://doi.org/10.1016/j.ijhydene.2017.04.096

Julpan, E. B. Nababan, and M. Zarlis, “Analisis Fungsi Aktivasi Sigmoid Biner Dan Sigmoid Bipolar Dalam Algoritma Backpropagation Pada Prediksi Kemampuan Siswa,” Jurnal Teknovasi, vol. 2, no. 1, pp. 103-116, 2015.

Jong, J.S. Jaringan Saraf Tiruan \& Pemprogramannya Menggunakan Matlab, Jogjakarta: Penerbit Andi. 2009.

Kasim, T., Aini, T.S., (2012). Teaching and Learning Experiences in Malaysian Higher Education: a Case Study of a Teacher Education Programme. Doctoral dissertation, Auckland University of Technology.

Katemba, P., \& Djoh, R. K. (2017). Prediksi Tingkat Produksi Kopi Menggunakan Regresi Linear. Jurnal Ilmiah FLASH, 3(1), 42-51. Retrieved from http://jurnal.pnk.ac.id/index.php/flash/article/view/136

Lesnussa, Y. A., Mustamu, C. G., Kondo Lembang, F., \& Talakua, M. W. (2018). Application of Backpropagation Neural Networks in Predicting Rainfall Data in Ambon City. International Journal of Artificial Intelligence Research, 2(2). https://doi.org/10.29099/ijair.v2i2.59

Mekparyup, J., Saithanu, K., \& Buaphan, M. (2014). Multiple linear regression analysis for estimation of nitrogen oxides in rayong. Global Journal of Pure and Applied Mathematics, 10(5), 769-774.

M. Najwa, B. Warsito, and D. Ispriyanti (2017), "Pemodelan Jaringan syaraf Tiruan Dengan Algoritma One Step Secant Backpropagation Dalam Return Kurs Rupiah Terhadap Dolar Amerika Serikat," Jurnal Gaussian, vol. 6, no. 1, pp. 61-70. https://doi.org/10.14710/j.gauss.v6i1.14768

Sakinah, N., Cholissodin, I., \& Widodo, A. (2017). Prediksi Jumlah Permintaan Koran Menggunakan Metode Jaringan Syaraf Tiruan Backpropagation. Jurnal Pengembangan Teknologi Informasi Dan Ilmu Komputer, 2(7), 2612-2618. Diambil dari http://j-ptiik.ub.ac.id/index.php/jptiik/article/view/1658.

Sumijan, A. P. Windarto, A. Muhammad, and Budiharjo (2016), "Implementation of Neural Networks in Predicting the Understanding Level of Students Subject," International Journal of Software 
Engineering and Its Applications, vol. 10, no. 10, pp. 189-204. DOI: 10.14257/ijseia.2016.10.10.18

Uyanık, G. K., \& Güler, N. (2013). A Study on Multiple Linear Regression Analysis. Procedia - Social and Behavioral Sciences, 106, 234-240. https://doi.org/10.1016/j.sbspro.2013.12.027 